\title{
Trayectorias militantes, izquierda y política sindical: la intervención del MAS en Sierra Grande a través de las vivencias de un obrero minero, Patagonia Argentina (1988-1991)
}

\section{Trajectories militants, left and trade union policy: MAS intervention in Sierra Grande through the experiences of a mine worker, Patagonia Argentina} (1988-1991)

\author{
Fernando Aiziczon*
}

\begin{abstract}
Resumen: El objetivo de este trabajo es describir el modo en que se intersectan la vida de un obrero minero, su trayectoria laboral, su militancia y su participación en la resistencia a la privatización de la mina HIPASAM (Sierra Grande, Patagonia Argentina). Estos aspectos permiten discutir y analizar los modos de compromiso político, el tipo de organizaciones militantes y el contexto histórico donde se despliegan. Se utilizan testimonios orales, publicaciones de organizaciones de izquierda y manuscritos inéditos para reconstruir la resistencia obrera en HIPASAM y la inexplorada deriva del MAS (Movimiento al Socialismo).
\end{abstract}

Palabras clave: trayectoria, testimonios militantes, política sindical, MAS, Argentina, Hipasam

\begin{abstract}
The aim of this paper is to describe how the life of a mine worker, his work history, its militancy, and its participation in the resistance to the privatization of HIPASAM mine intersect (Sierra Grande, Patagonia Argentina). These aspects allow to discuss and analyze the modes of political commitment, the type of militant organizations and the historical context where unfold. Oral testimony, publications leftist organizations and unpublished manuscripts are used to reconstruct the workers' resistance in HIPASAM and the unexplored derived from the MAS (Movement Toward Socialism).
\end{abstract}

Keywords: trajectory, testimonies militants, trade union policy, MAS, Argentina, Hipasam

Recibido:29 agosto 2016

Aceptado: 30 octubre 2016

\footnotetext{
* Argentino. Doctor en Historia. Investigador del CONICET (Consejo Nacional de Investigaciones Científicas y Técnicas) sede Instituto de Humanidades (IDH), docente en la Cátedra de Historia Social Argentina, Universidad Nacional de Córdoba. E-mail: feraizic@gmail.com
} 


\section{Testimonio, trayectoria, historia}

¿Qué dice (y qué omite) un testimonio, cómo traza un camino individual y cuáles son las reglas de su intersección con la vida colectiva?, ¿qué ocurre si ese testimonio es también de luchas sociales llevadas adelante por organizaciones de izquierda en la cual una persona se involucra?, ¿y qué podemos conocer respecto de las prácticas políticas y sindicales de la izquierda en un período determinado de la historia, más aún si la época es aquella en la cual se derrumban los "socialismos realmente existentes" y aparecen visiones críticas respecto de la condición militante?

Entrevistando a obreros de una fábrica en la provincia de Neuquén, norpatagonia argentina, nos anoticiamos de la existencia de un manuscrito perteneciente a Cristóbal Paz (en adelante Cristóbal P.), uno de los 450 obreros de esa fábrica, que mucho antes resultó ser obrero minero y militante de un partido de izquierda trotskista. Su manuscrito es luminoso por varias cuestiones: describe un proceso de lucha escasamente investigado (el cierre de la mina HIPASAM); ofrece una mirada microscópica de la vida política, sindical y afectiva entre los mineros; brinda elementos para el análisis de las prácticas políticas de la organización trotskista argentina más importante de las últimas décadas y con inserción en el movimiento obrero (el MAS); y finalmente permite una entrada al sinuoso universo del compromiso político expresado mediante el testimonio escrito. En vistas de ello, acordamos una entrevista con Cristóbal P. para conocer mejor la historia de ese manuscrito y, a través de su testimonio, la historia de inexploradas luchas de la clase obrera en la Patagonia argentina.

¿Por qué Cristóbal P. se vuelca a escribir? Nuestro protagonista ha sentido la necesidad de testimoniar su experiencia, de abrir un "espacio de inteligibilidad" en su vida", y esa necesidad, que lo une imaginariamente a otros tantos relatos biográficos, surge de la angustia, de la pérdida. La puesta en papel es el modo (y lo continúa siendo) en que muchos tramitan esa vivencia: Cristóbal P. quedó afectado por el cierre de su fuente laboral, la mina donde trabajaba, y se decidió a escribir:

Una vez que cerró la mina [1991]... escribí porque en el momento, no sé si llamarle un desahogo... al menos algunos de nosotros lo necesitábamos. El cierre de la empresa de alguna manera era un cambio completo en nuestras vidas: el trabajo, la vida hogareña, el contacto diario con los compañeros, y toda una serie de servicios que nosotros teníamos, como ser la vivienda gratis, luz, gas, agua, y el trasporte para movilizarnos de casa hacia el trabajo...

-¿Cómo te decidiste a escribir?

${ }^{1}$ Arfuch, Leonor El espacio biográfico. Dilemas de la subjetividad contemporánea. Buenos Aires, FCE, 2007.

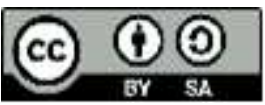


Tardé varios días. Eso sí, cuando empecé a escribir entendí que tenía que contar esa historia mía, que era a la vez la historia de mis compañeros, de los que trabajábamos en el yacimiento, que teníamos casi todos una vida muy similar en cuanto a la actividad laboral. ${ }^{2}$

“contar esa historia mía que era a la vez historia de mis compañeros"; el acento colectivo expuesto en la trayectoria individual de Cristóbal P. permite que su relato juegue en ese espacio intermedio entre memoria individual e historia de una clase: los modos de vida, orientaciones valorativas, prácticas de resistencia, identidades políticas y también la afectividad de los obreros mineros de Sierra Grande, provincia de Río Negro, Patagonia argentina. Y por lo mismo, es también un espacio intermedio entre lo personal y lo político que abre el juego a la dimensión del compromiso militante; en este sentido, comprendemos la actividad militante como una práctica social individual y dinámica ${ }^{3}$, desplegada procesualmente y sobre la cual es posible identificar en su interior fases que hacen a la comprensión general de una trayectoria; y una trayectoria, o también carrera ${ }^{4}$, no es más que la serie de posiciones objetivas ocupadas en organizaciones y/o instituciones (pero también su apreciación subjetiva) registrables mediante el recurso biográfico o el acceso al testimonio oral, desde donde es posible analizar cómo cada etapa biográfica pone en juego actitudes, comportamientos, afectos pasados que condicionan de modo relativo las posibles acciones venideras, pudiendo especificar períodos de compromiso político en el ciclo mayor de una vida. ${ }^{5}$ En este sentido, no buscamos únicamente el rescate de un evento desconocido, o la mera reconstrucción en base a testimonios, motivos válidos de debate para una historia oral (Leglise, 2013); más bien intentamos responder lo siguiente: ¿cómo se configura un determinado sujeto militante?, ¿cuál es el modo de intersección con eventos de lucha social?, ¿qué prácticas políticas y sindicales despliegan determinadas organizaciones de izquierda?

El escrito de Cristóbal P. no supera las 20 páginas, no fue publicado pero sí repartido entre pares (unas 20 copias), sin que el autor haya recibido devolución alguna. Cristóbal P. inició su militancia política en la mina, pero su escrito no responde al formato de una minuta, ni de un informe político, ni de un balance. Tampoco se ocupa de establecer causalidades respecto de la lucha contra el cierre de la mina. Pero sí identifica enemigos, establece una temporalidad, caracteriza la situación laboral, los sufrimientos de los obreros, y fundamentalmente tiene un título preciso que demarca el horizonte de análisis:

\footnotetext{
${ }^{2}$ Entrevista a Cristóbal Paz, Neuquén, 05/01 /2016.

${ }^{3}$ Ver Fillieule, Olivier "Propuestas para un análisis procesual del compromiso individual", en Intersticios. Revista sociológica de pensamiento crítico. Vol 9, Madrid, 2015.

${ }^{4}$ La noción crítica de trayectoria por oposición a la "ilusión biográfica" es desarrollada por Bourdieu en su libro Razones prácticas. Barcelona, Anagrama, 1997. La idea de carrera se encuentra desarrollada en Becker, Howard Outsiders. Buenos Aires. Siglo XXI, 2009. Para una propuesta de análisis de historias de vida que intersecta hechos, significados y su expresión subjetiva ver De Gaulejac, Vincent "Historias de vida y sociología clínica". Temas sociales 23, 1999.

${ }^{5}$ Ver Becker, Howard "Notes on the concept of Commitment", en American Journal of Sociology, núm 66, 1960.
}

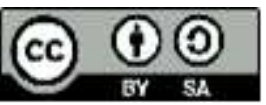


"Vivencias de un minero de la mina de HIPASAM". Su vivencia adquiere la forma de una "poética del saber" en el sentido que le atribuye Ranciere a los textos que rechazan la jerarquía de los discursos al no seguir la privilegiada retórica intelectual, sino que van en busca de una igualdad poética del mismo", una "autodidaxia", es decir, van más allá de la división entre el discurso que expresa una condición social y aquel que se ocupa de explicarla. Lo mismo vale como advertencia sobre el modo en que este material se impone a la praxis del historiador: el escrito de Cristóbal P. es accesible por contacto con su autor, con quien se logró a posteriori pautar una entrevista. La organización en la cual militó ya no existe, no posee archivos oficiales y apenas se encuentran algunas investigaciones exploratorias o escritos de militantes que siguen la lógica de las historias oficiales de las organizaciones partidarias ${ }^{7}$, por lo que nos valimos de minutas, circulares internas, informes de las regionales y periódicos partidarios que logramos encontrar.

\section{Chaco, Córdoba, Río Negro}

Cristóbal P. nace en el Departamento General Güemes, provincia del Chaco (nordeste argentino), el 16 de noviembre de 1950. Sus padres, también oriundos de esa provincia, siempre vivieron en el campo en condiciones de extrema pobreza, dedicándose a la cría de ganado y animales domésticos que apenas les aseguraba la subsistencia. Sin estudios primarios, la obsesión paterna era que sus hijos fueran a la escuela, distante a casi 15 kilómetros del hogar. Al terminar el ciclo primario Cristóbal P. retorna a las tareas hogareñas hasta que en el año 1968 por intermedio de un tío residente en Córdoba es enviado a aquella provincia para estudiar la tecnicatura en minería. Es un cambio grande en su vida: "yo era un joven de campo, netamente de campo y desconocía un montón de cosas." Al terminar sus estudios debe realizar el servicio militar obligatorio, y al finalizarlo una empresa le ofrece trabajar en "el emprendimiento minero más grande de Latinoamérica". Es una oferta inesperada y festejada por Cristóbal P., que pasa satisfactoriamente los exámenes médicos y el 7 de julio de 1976, con 25 años, ingresa a trabajar en la mina:

me adapté a todo. Los primeros años para mí fueron importantes. Respecto del salario nosotros llegamos a ser trabajadores privilegiados. Eso fue en plena dictadura y la dirección de la empresa eran todos militares retirados. Cada tres meses te daban un aumento de sueldo, el último día hábil del mes ya te pagaban ${ }^{9}$

\footnotetext{
${ }^{6}$ Ranciere, Jacques La noche de los proletarios. Buenos Aires, Ed. Tinta Limón, 2010.

${ }^{7}$ Los problemas metodológicos y de acceso a documentos planteados hace décadas por Anderson para estudiar los partidos comunistas persisten y se acentúan en las corrientes trotskistas. Ver Anderson, Perry "La historia de los partidos comunistas", en Samuel, Raphael (ed.) Historia popular y teoría socialista. Barcelona, Crítica, 1984.

${ }^{8}$ Entrevista a Cristóbal P., Neuquén, 05/01/2016.

${ }^{9}$ Ídem.
} 
El emprendimiento minero en cuestión es HIPASAM: Hierro Patagónico Sociedad Anónima Minera. Durante 1969, dentro de lo que se suele denominar como la fase autoritaria del desarrollismo ${ }^{10}$, el gobierno dictatorial de Onganía decretó ( $\mathrm{N}^{\circ}$ 4045/69) la formación de una empresa estatal para la explotación de yacimientos de hierro ubicados en Sierra Grande (sudeste de la provincia de Río Negro) cuyo objetivo principal era la promoción industrial y social de la región, y más estratégicamente, complementar el desarrollo de una industria siderúrgica nacional que lograra autoabastecer al país teniendo como eje principal a SOMISA (Sociedad Mixta Siderúrgica Argentina, creada en 1947 y puesta en funciones en 1960 como parte del Plan Siderúrgico Nacional). Este decreto surge luego de fracasar el aporte de capital privado; de allí que el estado nacional decida crear HIPASAM, que quedará bajo la órbita de la Dirección General de Fabricaciones Militares, la Provincia de Río Negro y el financiamiento del Banco Nacional de Desarrollo.

La creación de HIPASAM ciertamente fundó la pequeña localidad de Sierra Grande que hacia 1972 adquiere el estatus de municipio. La afluencia de contingentes de trabajadores del interior del país atraídos por los buenos salarios se mixturó con la presencia de empresarios contratistas de origen sueco, canadiense, alemán y japonés, que le dieron a Sierra Grande un carácter cosmopolita. No obstante ello, HIPASAM no es comparable a lo que fue la impronta sociocultural que produjo YPF o el también denominado "mundo ypefiano" en el sentido de generar un complejo de vida cotidiana inescindible de la idea de Estado benefactor, es decir, que asegura tanto condiciones materiales (vivienda, salarios altos, educación, recreación, etc.) como simbólicas (derechos sociales, pertenencia a un proyecto de desarrollo nacional) generando un espacio social totalizante que contiene al trabajador y su familia; por el contrario, HIPASAM creó desde sus cuadros directivos una vinculación paternalista, autoritaria y que fue percibida desde los obreros casi exclusivamente como una escuela de aprendizajes técnicos.

De acuerdo a los escasos estudios históricos sobre HIPASAM se puede decir que dos huelgas fuertes marcaron los años iniciales, ocurridas entre los años 1973 y 1975: la primera de ellas se desencadenó por demandas de mejoras en las condiciones de trabajo y seguridad, y en desacuerdo con la política patronal de asignación discrecional de viviendas.

${ }^{10}$ Altamirano, Carlos Bajo el signo de las masas (1943-1973) Buenos Aires. Ariel, 2001. Ver también Healey, Mark "El interior en disputa: proyectos de desarrollo y movimientos de protesta en las regiones extrapampeanas", en James Daniel (comp.). Violencia, proscripción y autoritarismo, 1955-1976. Nueva Historia Argentina Tomo IX, Buenos Aires, Sudamericana, 2003.

${ }^{11}$ Svampa, Maristella y Pereyra, Sebastián Entre la ruta y el barrio. La experiencia de las organizaciones piqueteras. Buenos Aires, Editorial Biblos, 2003. Para una crítica a la visión bienestarista en el caso de YPF ver Benclowicz, José Estado de malestar y tradiciones de lucha, Buenos Aires, Biblos, 2013. Véase también Rofman, Alejandro Las economías regionales a fines del siglo XX. Los circuitos del petróleo, del carbón y del azúcar, Buenos aires, Ariel, 1999. Para el caso de emprendimientos privados ver el clásico trabajo de Neiburg, Federico Fábrica y Villa Obrera: historia social y antropología de los obreros del cemento. Tomo 1 y 2. Buenos Aires, CEAL, 1998.Una discusión sobre el paternalismo patronal en estos tipos de asentamientos obreros puede encontrarse en Soul, Julia, Somiseros. La configuración y el devenir de un grupo obrero desde una perspectiva antropológica, Rosario, Prohistoria, 2015. 
En ausencia de representación sindical los obreros conformaron la seccional de AOMA Asociación Obrera Minera Argentina- que a posteriori se enfrentó con la UOCRA -Unión de Obreros de la Construcción de la República Argentina- por cuestiones relacionadas al encuadramiento sindical, lo que implicó la intervención de la seccional y el comienzo del accionar de patotas de la UOCRA para eliminar la incipiente oposición de izquierda a la dirección sindical. ${ }^{12}$ Esta primera gran huelga es recordada como exitosa porque logró el adicional por "zona inhóspita" dentro del contexto del "Pacto Social" implementado por el tercer gobierno peronista, que intentaba congelar salarios. La huelga del año 1975 se desarrolló en otro contexto: la devaluación y posterior escalada inflacionaria denominada como "Rodrigazo". Entre octubre y noviembre de 1975 los obreros ocuparon instalaciones de la mina en reclamo de mejores condiciones salariales, de trabajo y seguridad. ${ }^{13}$ A pesar de sufrir divisiones internas (la seccional de AOMA fue intervenida), de ser declarada ilegal por el Poder Ejecutivo y de sufrir la represión policial y del V Cuerpo de Ejército, los obreros en huelga lograron armar una red de apoyo y solidaridad hacia el conflicto recibiendo la solidaridad del gremio docente y de la mayoría de los partidos políticos con presencia en la provincia (UCR, Intransigente, Movimiento Integración y Desarrollo, Provincial de Río Negro, Partido Socialista de los Trabajadores, Partido Comunista Revolucionario). El saldo de esta huelga implicó el arresto y expulsión de la localidad de entre 300 a 400 personas y el despido de hasta 700 de los 1200 trabajadores de HIPASAM. Es que durante el conflicto se desarrollaron violentos enfrentamientos entre la policía y los huelguistas, que a su turno también se enfrentaron a sus conducciones gremiales. Al finalizar la huelga el sindicato quedó diezmado y sin activistas (uno de los lemas de las fuerzas represivas era "matar a todos los zurdos de Sierra Grande" "14 lo que posteriormente facilitó la aplicación de medidas flexibilizadoras como la ampliación de la jornada laboral de 6 a 8 horas y abrió las puertas a despidos anuales sistemáticos para descomprimir malestares internos.

Ya durante el período de transición democrática el gobierno de Alfonsín intentó privatizar SOMISA, tildada de obsoleta y deficitaria, al tiempo que la siderurgia estatal perdía mercados a manos de los nuevos "capitanes de la industria" surgidos de la fusión de los capitales privados ACINDAR y SIDERCA. Lógicamente HIPASAM como proveedora de SOMISA era sensible a esta coyuntura, en especial cuando en 1988 el gobierno le suspendió los subsidios y se conoció el interés del empresario Jorge Alemann (ex ministro de Hacienda durante la última dictadura) de abastecer a SOMISA desde Brasil para disminuir costos, lo cual implicaba el cierre de HIPASAM. Así, en un clima político que

\footnotetext{
${ }^{12}$ Ver Gouarnalusse, Juan Manuel "Gran proyecto y conflictividad política”, en IX Congreso Argentino de Antropología Social, Posadas, 2008.

${ }^{13}$ Otros reclamos incluían el modo en que las autoridades militares llevaban a cabo el programa de desarrollo de la localidad, el reconocimiento de la representatividad de delegación sindical por parte de la empresa, la participación obrera en el control de las áreas de servicio (transportes, comedor, sanidad, recreación), la integración al consejo de dirección de las mismas, la residencia de los altos funcionarios de la empresa en la localidad, la reiniciación de las obras del policlínico regional y la finalización de las mismas en plazos contractuales. Ver Gouarnalusse, op. cit.

14 Ídem, p. 11.
} 
atacaba el déficit de las empresas estatales, su falta de competitividad, el sobredimensionamiento de personal, o el alto costo salarial que las supuestas demandas gremiales ocasionaban, encontramos nuevos conflictos en HIPASAM como el que se desató por la negativa patronal a pagar el "premio al esfuerzo solidario" (un adicional semestral implementado en 1987 a cambio de que los obreros acepten diversificar sus funciones). Este conflicto dejó ver además que los obreros demandaban también la cogestión o el control obrero como modo de contrarrestar gastos superfluos. ${ }^{15}$

Finalmente, en agosto de 1989 fue designando Hugo Franco como presidente de SOMISA quien sería el encargado de preparar su privatización y la de Altos Hornos Zapla en Jujuy. En mayo de 1991 fueron intervenidas SOMISA e HIPASAM: en SOMISA fue nombrado Jorge Triaca (sindicalista de extracción peronista y ex Ministro de Trabajo), en HIPASAM quedó al frente Jorge Berzano. La intervención de HIPASAM fue decretada el 29 de mayo de 1991 y a los pocos días la empresa cerró. Sindicatos y una Multisectorial ("Foro de Sierra Grande") intentaron negociar con la intervención del gobernador de Río Negro, Horacio Massaccesi, con la intención de que se provincialice HIPASAM. Mientras, ya se ofrecían retiros voluntarios que eran aceptados por 50 de los 1300 obreros de entonces. ${ }^{16} \mathrm{Al}$ no efectuarse el pago de las indemnizaciones comenzaron a sucederse los primeros cortes de ruta. El punto más álgido ocurrió cuando una delegación de obreros de HIPASAM marchó a Buenos Aires a fines de setiembre para manifestarse frente al Congreso Nacional y la Casa Rosada mientras en Sierra Grande la ruta permanecía cortada y las escuelas tomadas. Si bien los ministros Erman González, Domingo Cavallo y José Luis Manzano negociaron pagar los salarios atrasados y la reapertura de HIPASAM, los trabajadores no pudieron volver a sus puestos por falta de insumos. Esto produjo que los obreros partieran nuevamente a Buenos Aires para confluir con los obreros de SOMISA en una marcha desde Congreso a Plaza de Mayo. Entre idas y venidas, negociaciones truncas, alrededor de 8000 obreros de SOMISA y Altos Hornos aceptaban el retiro voluntario. Hugo Riesco, el dirigente sindical que encabezó los trabajadores de HIPASAM declarará en esos días a la prensa que "ya no hay nada para hacer."17

\section{Trabajo y Política en HIPASAM según las “Vivencias... ” de Cristóbal P.}

Veamos ahora como las "Vivencias..." nos permiten ingresar desde un ángulo subjetivo al derrotero de los trabajadores de HIPASAM. Lo primero que destaca Cristóbal P. en los inicios de estas Vivencias es el perfil de la patronal, recordemos, a cargo de militares:

eran botudos [sic], retirados o en actividad; al menos cuando aparecían en el yacimiento, vestían botas y charreteras (...) y el que

\footnotetext{
15 Ver Rivero, Cynthia "Confusión organizada, arbitrariedad conciente: imágenes en torno a la deslegitimación de las empresas del Estado", ponencia en las $9^{\circ}$ Jornadas Rosarinas de Antropología Sociocultural, Rosario, 2007.

${ }^{16}$ Ídem, p. 12.

${ }^{17}$ Ídem, p. 14.
} 
tibiamente hacía una referencia de descontento recibía un 'a $U d$. Eso no le compete, 18

En su mayoría compuesto por obreros jóvenes (hay que recordar las camadas de activistas despedidos tras las huelgas de 1973-75), sin experiencia política, solían autodefinirse como trabajadores "privilegiados": buenos salarios, comida, elementos de seguridad, servicios, transporte al lugar de trabajo, alojamiento con todos los servicios gratis para el personal soltero, vivienda para el grupo familiar gratis, al menos hasta fines de los '70.

A pesar de que Cristóbal Paz ingresa en 1976 no registra las luchas de los años 1973-75, aunque sí describe un conflicto a fines de 1977 que se desató al anoticiarse los obreros de que el aumento salarial traía como novedad que un $30 \%$ del incremento pasaba a considerarse "premio por asistencia", una suerte de presentismo que impactó en la imposibilidad de faltar por enfermedad u otras razones. En ese entonces el plantel que recuerda Cristóbal P. ronda los 1600 obreros, más 500 pertenecientes a empresas contratistas. Hacia 1980 Cristóbal P. comenta que los obreros solteros pierden el derecho al alojamiento y comida gratuita, y comienzan a registrarse aumentos salariales individualizados y una sistemática reestructuración de personal. Al mismo tiempo, HIPASAM producía a un $30 \%$ de su capacidad operativa y ya recibía quejas por la baja calidad de los "pellets" de hierro que debían destinarse a SOMISA y ACINDAR. Son los prolegómenos de los intentos de cerrar la mina, como describimos en el apartado previo:

\begin{abstract}
ya se empieza a hablar de que el Estado no puede seguir subsidiando porque era un proyecto poco viable, o que tenía que mantenerse con su propia producción (...) El sr. Aleman (sic) opinaba que había que bajar las persianas (...) nuestras opiniones iban desde que no podía ser posible que semejante infraestructura quedara abandonada en la soledad con lo que ello implicaba, llevarse la vida de un pueblo de 12.500 habitantes (...) hasta que éramos capaces de autoabastecernos y de última mantener la fuerza de trabajo ${ }^{19}$
\end{abstract}

Entre la incredulidad de los obreros frente a un eventual cierre, Cristóbal P. comenta que ocurren las elecciones para constituir la comisión directiva de la delegación Sierra Grande de AOMA, donde se enfrentan dos listas para completar un cuerpo de delegados de once miembros: la lista Celeste y Blanca que postulaba al chofer de camiones minerales de apellido Siguero, de extracción peronista, como secretario general, vs la lista Naranja que postulaba a Hugo Riesco, "ligado a la Iglesia, de función administrativo con vasta experiencia como liquidador de sueldos y jornales", quien resultará ganador por 24 votos. ${ }^{20}$

\footnotetext{
${ }^{18}$ Cristóbal P., Vivencias de un minero de la mina de HIPASAM, manuscrito, Río Negro, 1991, p. 1.

${ }^{19}$ Ídem, p. 4.

${ }^{20}$ Ídem, p. 5.
} 
El conocimiento de la maquinaria salarial por parte de Riesco sumó voluntades obreras en la creencia de que sabría defenderlos de las maniobras patronales. La asunción de Riesco es contemporánea al alfonsinismo, y los cambios en el ejecutivo son correlativos a cambios en el directorio de HIPASAM, que se suceden a gran velocidad. Cristóbal P. recuerda los trece paros generales que la CGT lanzó al gobierno de Alfonsín y su repercusión en la mina: "en nuestro gremio se hacían algunas veces una sola asamblea y se tomaba alguna decisión, en general se plegaba a la medida”. Para Cristóbal P., Riesco era un gran caudillo, sabía hablar y explicar sus posiciones en asambleas, poseía un cuerpo de delgados fiel, y capitalizaba desde las huelgas lanzadas por la CGT hasta los aumentos salariales decretados por los diversos directorios, la mas de las veces con fuertes vínculos con el propio Riesco: "la mayoría de los compañeros apoyaban sus planteos que resultaban ser convincentes por ser expresados por un gran orador." 21 Además, Riesco va a llevar adelante la creación de una mutual para la "familia minera" desde la cual implementará prácticas de beneficencia y clientelismo como la distribución de útiles escolares, artículos de almacén y electrodomésticos. Luego vendrán la adquisición de un auto, una camioneta $0 \mathrm{~km}$, computadoras y otros artefactos materiales en beneficio del sindicato, fruto según Cristóbal P. de la buena relación entre Riesco y AOMA. Más adelante, un conflicto de 60 días de duración bajo la primera gobernación de Horacio Massaccesi (1987-1991) consolidará la gestión de Riesco ya que el resultado es exitoso: tras una caminata a la capital de Río Negro (Viedma) reclamando el reconocimiento del convenio colectivo y que incluyó acciones como ollas populares, instalación de carpas en la plaza principal de Viedma y el apoyo activo del pueblo de Sierra Grande, el sindicato sale airoso y las bases festejan el logro obtenido mediante lucha y asambleas, donde emergen también liderazgos que no responden a Riesco, como el que representa el "compañero campito (sic)", sobre el que volveremos más adelante. El triunfo también abre las puertas a la propuesta de participación de los trabajadores como acreedores de HIPASAM aunque de modo desigual pues, siguiendo el testimonio de Cristóbal P., la dirigencia sindical sacaría la mayor tajada; de allí que Riesco sea rebautizado como "el Maradona del equipo" o "el ángel rubio": su poder es incuestionable, sus palabras son reproducidas por la prensa regional y se muestra frente a la patronal como un sindicalista "duro". 22 No obstante, el poder de Riesco comenzará a ser disputado lentamente: nuevas elecciones de un cuerpo de delegados que se amplía de once a dieciséis miembros permite visualizar cierta autonomía que irán adquiriendo estos delegados a los que se suma la novedad del desembarco de una corriente de izquierda cuyos escasos militantes comienzan a sembrar de volantes la localidad de Sierra Grande. Cristóbal P. describe esta novedad resaltando lo inusual de su presencia.

\section{La intervención del MAS en Sierra Grande}

con sus volantes, sus pintadas, se ve circular un periódico; cada vez tomaba más fuerza. Capta a algunos obreros de la mina y abre un

\footnotetext{
${ }^{21}$ Ídem, p. 7.

${ }^{22}$ Ídem, p. 9.
} 
local partidario; del anonimato pasa a tener presencia política a través de sus militantes y dirigentes: estaban presentes en todos lados, en las asambleas de la mina, en la intersectorial, así fue que en el cuerpo de delegados había cuatro militantes y uno en Comisión Directiva ${ }^{23}$

Cristóbal P. habla aquí de la penetrante intervención del MAS en Sierra Grande, de cómo cambió con un "nuevo lenguaje" el clima político en la mina. Resulta interesante que el oficialismo de AOMA, y en especial Riesco, toman nota de la presencia de activistas de izquierda ("zurdos"); y esa presencia provoca dos reacciones: primero, el intento, exitoso, de desplazar a estos delegados, cuestión que se logra mediante la expulsión de todos ellos; y segundo, Riesco y sus militantes se apropiarán del discurso combativo que es propagado desde otros activistas de base: nociones como "solidaridad obrera", el no pago o crítica de la Deuda Externa, al FMI, la necesidad de democracia en las asambleas o de que los dirigentes respondan a sus bases, entre otras, son reproducidas por Riesco como una táctica para neutralizar la simpatía que despierta este nuevo vocabulario entre los obreros. En este punto lo destacable es que las "Vivencias..." de Cristóbal P. comienzan a hablar desde el lugar de un activista de izquierda, como si el autor reiniciara su testimonio ahora bajo la voz (y la mirada) de un militante: por ejemplo esto ocurre cuando Cristóbal P. comenta que Riesco comienza a utilizar "nuestra línea",24, es decir, la línea del MAS, el partido donde ya comienza a militar Cristóbal P. Nótese que inmediatamente antes, el tono de las "Vivencias..." es estrictamente personal ("sus pintadas, "sus volantes").

Los escasos estudios sobre el Movimiento Al Socialismo (MAS) coinciden en explicar su fundación dentro del contexto de las transiciones democráticas pos dictaduras latinoamericanas, bajo un clima político y un discurso democratizante y pro-derechos humanos que coincide involuntariamente con el propagado desde la gestión de James Carter (EEUU, 1977-1981) con el objetivo de desviar procesos revolucionarios que se venían desarrollando (p.e., Nicaragua). ${ }^{25}$ Más allá de esto, en la visión de su máximo referente, Nahuel Moreno, ${ }^{26}$ y ya desde su antecesor, el PST (Partido Socialista de los

\footnotetext{
23 Ídem, p. 10.

24 Ídem, p. 10.

${ }^{25}$ Liszt, Gabriela "Historia y balance del MAS argentino", en Revista Lucha de clases, número 6, Buenos Aires, IPS, 2006. La reconversión de militantes que habían iniciado su actividad política en organizaciones revolucionarias armadas durante los años ' 70 y que luego de la traumática experiencia represiva abrazaron la vía democrática se encuentra desarrollado en Ollier, Matilde De la revolución a la democracia. Cambios privados, públicos y políticos de la izquierda argentina. Buenos Aires, Siglo XXI, 2009. Ver también Hilb, Claudia y Lutzky, Daniel La nueva izquierda en argentina: 1960-1980. Política y violencia, Buenos Aires, CEAL, 1984.

${ }^{26}$ Nahuel Moreno es Hugo Miguel Bressano Capacete, quien desde los años 40 militó en distintas organizaciones trotskistas: Grupo Obrero Marxista (GOM); Partido Obrero Revolucionario (POR); Partido Socialista de la Revolución Nacional (PSRN); Movimiento de Agrupaciones Obreras (MAO), desde practicó el denominado "entrismo" en el movimiento obrero peronista, identificado también por el nombre de su órgano de prensa: Palabra Obrera; luego sigue fundando el Partido Revolucionario de los Trabajadores (PRT); Partido Revolucionario de los Trabajadores "La Verdad” (PRT-LV); Partido Socialista de los Trabajadores
} 
Trabajadores, fundado en 1972), existía una voluntad política de identificación con las experiencias de los grandes partidos socialistas europeos, en especial el PSOE, de allí que años más tarde Nahuel Moreno publique su famoso escrito inmediato a la derrota en la Guerra de Malvinas titulado "1982, empieza la revolución” y se vuelque a la fundación (setiembre de 1982) de un gran partido socialista de masas cuyo horizonte de intervención más cercano era el llamado a elecciones en 1983. Para ello, todo el viejo PST pasa a integrar el $\mathrm{MAS}^{27}$ tomándose como base la "Declaración de principios" del Partido Socialista de Juan B. Justo (1896), convocando a confluir en él al PSP, PSA. PSD ${ }^{28}$ y excluyendo a los socialistas "totalitarios", es decir, al PC, con quienes años más tarde formarán un frente electoral. ${ }^{29}$

La inserción del MAS se destacó en la dirección de gremios como la Asociación del Personal de los Organismos de Previsión Social (APOPS) de Capital Federal, la Unión Obrera de la Construcción de la República Argentina (UOCRA) regional Neuquén ${ }^{30}$ y seccionales ferroviarias, docentes y bancarias, mas cierta influencia en la Asociación de Trabajadores de la Sanidad (ATSA) también de Capital Federal. ${ }^{31}$ Los datos disponibles hablan de más de 500 locales abiertos en todo el país hacia 1983, con epicentros ubicados en el Gran Buenos Aires, Santa Fe y Córdoba. En términos de eficacia electoral el MAS duplica y hasta cuadruplica sus votos a lo largo de la década, conquistando dos diputados en 1989: Luis Zamora (nacional) y Silvia Díaz (Buenos Aires). ${ }^{32}$ En 1988 el MAS

(PST) y, finalmente, el Movimiento al Socialismo (MAS). Ver Brienza, Hernán Nahuel Moreno: El trotskismo criollo, Buenos Aires, Capital Intelectual, 2006.

${ }^{27}$ Según Sager "el naciente partido tuvo basamento organizativo en 600 cuadros del PST, que se avocaron a abrir locales partidarios y a estructurarse en la clase obrera, mayoritariamente en el sector servicios". Ver Sager, Federico "Tras las huellas del estallido partidario. Análisis de balances militantes de los años noventa sobre el Movimiento al Socialismo argentino", III Jornadas Internacionales de Problemas Latinoamericanos. Facultad de Ciencias Políticas y Sociales. UNCuyo, Mendoza, 2010. En CD. ISBN-978-987-9441-65-7.

${ }^{28}$ Partido Socialista Popular, Partido Socialista Argentino, Partido Socialista Democrático, respectivamente.

${ }^{29}$ Ídem. El Programa del MAS hablaba de una "segunda independencia nacional y continental" en el contexto de una "crisis agónica del capitalismo semicolonial", con un peronismo que atravesaba una "crisis generalizada" caracterizada porque "la masa obrera peronista ya no lo reconoce ni obedece como dirección sindical y política", y donde la estrategia pasaba por convocar a "pequeños productores y clases medias" en alianza con la clase obrera formando un Partido de los Trabajadores, donde tendrían cabida dirigentes de extracción peronista como Ongaro o Piccinini. Ver Programa del MAS, julio de 1985. Para la problemática vinculación entre trotskismo argentino y peronismo ver Rojo, Alicia "El trotskismo argentino y los orígenes del peronismo", en Cuadernos del CEIP, N³, Agosto de 2002; y los clásicos estudios de González, Ernesto, El trotskismo obrero e internacionalista en la Argentina, tomo 1, Buenos Aires, Editorial Antídoto, 1995, y Coggiola, Osvaldo, El trotskismo en la Argentina, Buenos Aires, CEAL, 1985.

${ }^{30}$ Aiziczon, Fernando "Construyendo tradiciones. Activistas de izquierda en las luchas de los obreros de la construcción de Neuquén a fines de los años '80", en revisa Izquierdas, Año 3, Número 5, Chile, USACH, 2009. Disponible on line: http://www.revistas.usach.cl/ojs/index.php/izquierdas/article/viewFile/937/887

${ }^{31}$ Liszt, Gabriela, op. cit. Ver también la participación del MAS en las huelgas generales del período en Carrera, Iñigo "Las huelgas generales, Argentina 1983-2001: un ejercicio de periodización", Buenos Aires, PIMSA, Documento de trabajo №33, 2001.

${ }^{32}$ Los votos obtenidos para diputados nacionales -categoría en la que tuvieron mejor resultado-, pasaron en Buenos Aires del 0,55\% (30.434 votos) al 2,47\% en (145.381 votos) y en Córdoba, del 0,23\% (3.202 votos) al 0,48\% (7.130), respectivamente. Ver Sager, op. cit., p. 5. 
conforma un frente electoral denominado Izquierda Unida, donde participa el Frente Amplio de Liberación (FRAL), hegemonizado por el Partido Comunista (PC), con quienes compite en elecciones internas. Respecto a la cantidad de militantes, Sager cita una publicación que señala que al momento de la ruptura (año 1992) el MAS superaba los 5000 miembros. ${ }^{33}$ En efecto, el MAS no cumplirá una década de existencia cuando una aguda crisis interna termine con la experiencia partidaria, paradójicamente en el momento en que lograba interesantes resultados electorales y alcanzaba una nada despreciable influencia en los sectores más activos del movimiento obrero. Una de esas influencias se verá precisamente en HIPASAM, y uno de los militantes sobre los que impactará la deriva del MAS será la trayectoria militante de Cristóbal P.

¿Cuáles son los signos de la crisis partidaria y cómo llegan a Sierra Grande y a Cristóbal P.?, algunos documentos internos hablan de un "retroceso desordenado" del MAS visible en la falta de intervención en la lucha de clases, luchas que a las que precisamente se había propuesto "volcarse por entero", y que en orden de importancia fueron planificadas contra la privatización de SOMISA y ACINDAR, y por decantación, HIPASAM; en todos ellos solo se tuvo una "orientación propagandística", según documentos muy críticos. ${ }^{34}$ En especial dos documentos regionales abarcan esta crisis y el modo en que impactó en HIPASAM: Elementos para un balance provisional (21/11/1990) y Minuta de los compañeros del partido en Sierra Grande (01/07/1991). Ambos se ocupan de los mismos problemas, pero gana en precisión el segundo quizás porque utiliza como borrador al primero. Por ejemplo, la periodización en dos etapas es complejizada en tres etapas en el segundo documento, que cuenta además con análisis detallados y una conclusión más clara. Ambos están firmados por siete militantes del MAS de Sierra Grande entre los que se encuentra Cristóbal P. El primero de ellos nos permite adentrarnos en cómo caracterizó el MAS a la provincia de Río Negro y en particular a Sierra Grande, donde se traza la siguiente cuadro de situación:

33 Ídem, p. 4. El artículo citado es Divés, Jean-Phillipe, "Elementos para un balance de la LIT y el morenismo", en Construir otro futuro. Por el relanzamiento de la revolución y el socialismo, Buenos Aires, Editorial Antídoto, 2002. Es interesante destacar la propia dirigencia del MAS lo consideraba el partido trotskista "mas grande del mundo", ver Moreno, Nahuel, El partido y la revolución, Buenos Aires, ed. Antídoto, 1989.

${ }^{34}$ Ver "Al secretariado internacional, al CE, al CC y a los partidos hermanos", informe interno de la regional Río Negro, 20/11/1991, p. 2-3. En el anexo a la Circular Interna del 13/06/1991 del MAS dedicada a SOMISA ya se encuentra una crítica a la intervención del MAS aun contando con una caracterización bastante certera del plano de situación político-sindical: "El CC votó seguir Somisa como uno de los frentes más importantes (...) Somisa es una industria siderúrgica donde trabajan 12000 trabajadores y 1500 compañeros de empresas contratistas (...) eje natural para el movimiento obrero de Hipasam, Altos Hornos Zapla, como así también para la industria privada de Acindar, Dálmine, Techint y Propulsora (...) La burocracia. Brunelli y Lorenzo Miguel coinciden con el plan estratégico del gobierno. La diferencia que hoy tiene con el gobierno es tener un rol en el plan privatizador. Es decir, la diferencia es táctica, pero no deja de ser importante para tenerla en cuenta (...) Centralmente el objetivo de Brunelli además de buscar este rol de la UOM pretende quedarse con una parte de las acciones como lo dijo en más de una oportunidad "con el $20 \%$ de las acciones" (...) Nuestro programa para este proceso lo debemos definir bien, ya que no venimos golpeando bien con un programa de transición para SOMISA por las dificultades que tiene el partido (...) hace que lo central sea la denuncia y el enfrentamiento". Negritas nuestras. 
sin lugar a dudas es la concentración obrera más importante de la provincia ya que es una empresa-pueblo con unos 1200 obreros mineros. Al ser una empresa del estado, está sufriendo el desmantelamiento y la incertidumbre (...) va a ver [sic] una racionalización con despidos de personal que lo reducirán unos 800 ó 900. Es una empresa que depende totalmente de Somisa y al no estar claro el destino de esta tampoco está para Hipasam. ${ }^{35}$

Este documento establece dos períodos ligados a dos conflictos donde el MAS ya tiene participación, y que es presentado como anexo que sirve de periodización del trabajo en Sierra Grande: el primero, datado en la huelga de 1988 el MAS interviene "desde afuera", es decir, desde la ciudad capital de Río Negro (Viedma) que es el lugar adonde llegan los obreros en huelga tras una caminata desde Sierra Grande en reclamo de la aplicación del convenio colectivo de trabajo. Allí se milita rodeando de solidaridad y entablando los primeros contactos, para lo cual se busca impactar con visitas de militantes reconocidos del histórico sindicalismo clasista de los años ' 70 desarrollado en la provincia Córdoba, como el caso del "petiso Páez" quien participa de la marcha. Hasta ese entonces "nuestros contactos se limitaban a visitas esporádicas que realizaba 'campito' [Víctor Campos] a Bs. As." En abril de 1989 los obreros vuelven a entrar en conflicto, y la intervención del MAS es directa, y cuenta nuevamente con la visita de personalidades nacionales del partido:

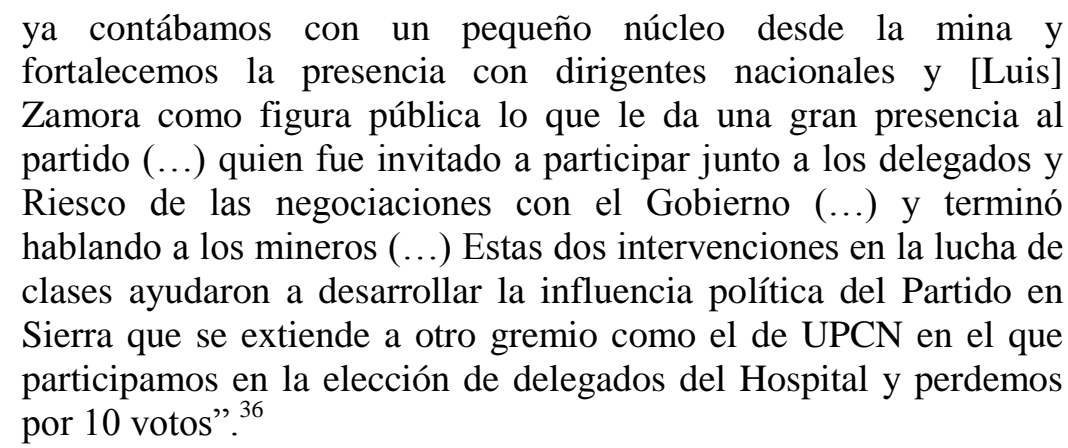

Este período es también denominado de "apertura y captación". La visita del dirigente más visible del partido, Luis Zamora, sirve también para una charla-debate en el nuevo local del MAS en Sierra Grande donde asisten unas 150 personas. ${ }^{37}$ Ponderadas como exitosas, estas actividades permiten que el partido decida la instalación de un militante ("Daniel") que contará con el apoyo desde la regional de la provincia de Neuquén (distante a $530 \mathrm{~km}$ ).

\footnotetext{
35 "Elementos para un balance provisional", 21/11/1990, p.2.

${ }^{36}$ Ídem, p. 1.

37 "Minuta de los compañeros del partido en Sierra Grande", 01/07/1991, p.1.
} 
El segundo período es denominado "de consolidación de esa influencia", o también de "afianzamiento de la propaganda" según el segundo documento ${ }^{38}$, aunque la política nacional "era difusa, sindical y políticamente". Lo que se consolida localmente es la formación de dos equipos preexistentes y una "mesa de responsables" con las "debilidades propias de una falsa armazón política". No obstante, la pequeña regional interviene en los primeros acontecimientos políticos partidarios provinciales como el Congreso Patagónico que lo tuvo a "Campito", militante minero del MAS, como uno de los responsables organizativos pero a quien se le critica estar "por fuera de toda discusión orgánica partidaria, más bien subordinado a la burocracia de Riesco". ${ }^{39}$ Estos equipos serán luego tres: uno sindical (con "Daniel" dirigiendo) donde se reúnen entre 15-20 militantes en su pico máximo.

El trabajo de este equipo logra meter al partido a fondo dentro de la mina repartiendo la prensa, haciendo campañas, sacando volantes y abriendo la discusión política dentro de distintos sectores del yacimiento, logrando de esta forma meter tres delegados (Cristóbal Paz, Roberto K. en Punta Colorada y Víctor O. en lámina) y la participación de otros compañeros como candidatos a delegados que pierden por escaso margen ${ }^{40}$

Un segundo equipo es el de la juventud el cual es tomado por "Pablo" que reúne una docena de militantes que desarrollan actividades como la difusión de videos, charlas de discusión política, peñas y pintadas. El tercer equipo es una conjunción de militantes que intervienen de UPCN, docentes, independientes, y con los cuales se logró:

sacar el partido hacia afuera, tener una participación embrionaria en las escuelas, enfrentar la burocracia de UNTER [gremio docente rionegrino], lograr por iniciativa del partido que se nombraran delegados en las escuelas elegidos democráticamente por la base, realizar piqueteos en los barrios La Loma e Industrial, reunir en esos mismos barrios más de 30 compañeros $^{41}$

\footnotetext{
38 Ídem, p. 1. Esta etapa se puede unificar con una tercera etapa que presenta el segundo documento denominada "Etapa de politización", que comienza con la llegada a la localidad de "Julio y la Negra" en febrero de 1990, "encontrando un partido en el que se reunían una importante cantidad de compañeros, un secretario gremial interior de AOMA (Víctor) y tres delegados (dos por Punta Colorada y uno por Mina, Cristóbal Paz, Roberto K, y Víctor) en un consolidado equipo de Hipasam y un grupo de compañeros de UPCN junto a independientes de otro quipo (Mario, Elba, Carlos, Ramón, Pedro, Liliana, Andrés, Rulo, Rosa)". En este año se realiza el único curso de formación política (marzo de 1990) y en abril de 1990 se participa del Tercer Congreso Patagónico del MAS "donde tenemos una gran actuación del partido de conjunto y pobre como partido local", p. 2, negritas nuestras.

${ }^{39}$ Ídem, p. 1.

40 "Minuta de los compañeros del partido en Sierra Grande", 01/07/1991, p.1. Negritas nuestras.

${ }^{41}$ Ídem, p.1. Sin embargo, la Regional decidirá sin discutir con los equipos locales sacar a dos militantes de la Juventud, lo que producirá la desintegración de este equipo; y acto seguido, hará lo mismo sacando a otros dos militantes, cuyo efecto inmediato será la desaparición de la influencia embrionaria lograda dentro de las escuelas.
} 
Sin embargo, en esta parte del documento ya pueden apreciarse las tensiones respecto de cómo "utilizar" a un cuadro carismático en la mina, el mencionado "Campito", para que rinda eficazmente en la construcción partidaria, a pesar de que su formación política (“débil") lo lleva a cometer "desvíos" cuya responsabilidad le cabe al partido:

a tal punto llegó esta política de abandono de los objetivos estratégicos del partido que permitió que este compañero estuviese desarrollando profundos rasgos burocráticos (...) consideramos que teníamos que empezar a dar una batalla a fondo para combatir estas desviaciones en el compañero que era sin lugar a dudas el referente político del MAS ante los obreros de Hipasam, a quienes parecíamos como la pata izquierda de la burocracia de Riesco que nos empezaba a arrastrar en su desprestigio. ${ }^{42}$

Según se describe, Riesco estaba comprometido en hacer participar al sindicato en una Sociedad Anónima (denominada "Argenhim") accediendo al 30\% de las acciones de la empresa para lo cual contaba con el apoyo incondicional del nuevo presidente de HIPASAM, Luis Rachid, designado bajo el gobierno de Carlos Menem, quien junto a Riesco hablaban de "autogestión empresarial. "Campito" solía estar muchas veces "pegado" a Riesco, es decir, no se diferenciaba tajantemente o no decidía enfrentarlo políticamente por temor a que las bases lo rechacen, pero esta táctica le volvió en contra cuando la comisión directiva del sindicato comenzó a acusarlo de responder al MAS (los "zurdos"), lo que fue visto por las bases no como una lucha ideológica sino como una pelea entre dirigentes. El análisis político del documento dictamina una "falta de politización" incluso en obreros que eran considerados "de vanguardia" ya que apoyan (se asocian) la propuesta de Riesco ${ }^{44}$. Es más, “Campito” será expulsado de la dirección del sindicato, a lo que se responderá con una carta pública que no es discutida entre los miembros del equipo sindical del MAS, que a su vez se desbanda tras la separación del cargo de "Campito".

Tras estas dificultades el MAS reacciona apresuradamente conformando un "polo opositor", que no es más que una nueva agrupación que denominó Democracia Obrera, y que logró aglutinar a un importante grupo de activistas. No obstante, el segundo documento reniega de la creación de esta agrupación ya que sostiene que no logra captar la periferia que simpatizaba con el MAS y esa situación produce que Democracia Obrera sea vista y

\footnotetext{
42 "Elementos para un balance provisional", 21/11/1990, p. 2.

${ }^{43}$ Cristóbal P. cuenta en sus Vivencias que "muchos compañeros ya se sentían empresarios, o gerentes", y que Riesco les hablaba de sus "acciones y cotizaciones en bolsa", reprendiendo públicamente a aquellos que no comprendían los nuevos tiempos y que en consecuencia "seguirían siendo pobres", como los "zurdos" que se oponen a la autogestión. "Vivencias...", p. 12-13.

44 "Minuta de los compañeros del partido en Sierra Grande", 01/07/1991, p. 3.
} 
funcione como un apéndice del MAS, y por lo tanto se comporte de manera "sectaria", "sin tener en cuenta la opinión de la vanguardia."45

Ahora bien, ¿cuál era la influencia que el MAS se adjudicaba en la mina? Valgan estos datos extraídos de las fuentes partidarias citadas: el sector Punta Colorada, donde trabajan unos 150 obreros, se lograr influenciar a 25, de los cuales 15 se reúnen políticamente y reciben Solidaridad Socialista (periódico del MAS), y 14 de ellos cotizan. En el sector minas, bastión de Riesco, el MAS posee un delegado e influencia sobre 13 obreros, 3 de ellos cotizantes discontinuos. El sector administrativo suele participar de la distribución de volantes, visitan el local del partido para discutir "la línea", y casi todos colaboran con la campaña financiera. ${ }^{46}$

En agosto de 1990 hay elecciones de delegados. Para la pelea contra "la burocracia" de Riesco el MAS apuesta todo a que "Campito" se imponga, pero descuida a otros militantes que también son respetados aunque no tienen el carisma de aquél; es el caso de "Roberto" y de Cristóbal P., que pierde por un voto la posibilidad de ser también electo delegado: "El triunfo político logrado por la elección de Campos se opacó por la pérdida de Cristóbal Paz",47, y esto sucede "por no haber invertido el partido absolutamente [nada] en su postulación" 48 . Pero siguiendo la lectura del documento en este escenario ocurre lo peor: "Campito" observa el error que se comete "y desaparece orgánicamente del partido por unos días y decide participar de la elección de delegado de mina por su cuenta, sin la participación del partido, ganando por amplia mayoría." ${ }^{\text {,4 }}$ No obstante esta falta de disciplina, siempre según los parámetros del MAS, el prestigio de "Campito" hace que el partido le ofrezca integrar como candidato a vice gobernador (presentado como "minero de

\footnotetext{
${ }^{45}$ Un volante de la agrupación Democracia Obrera permite conocer la situación política y laboral de los obreros: "En estos días difíciles por los que estamos pasando los obreros de HIPASAM, existe una gran confusión y como lo hicimos en otras oportunidades queremos aportar a la discusión tratando de que entre todos salgamos adelante (...)nos empezaron desconociendo el convenio (...) no nos pagaron los aumentos, nos dan en cuentagotas el salario nos reducen los colectivos, no nos dan elementos de seguridad, etc. (...) El mejor ejemplo de esto lo tuvimos en ACINDAR donde la patronal había contratado a un montón de desocupados de Rosario para hacerlos trabajar por la mitad del salario (...) Es decir, en HIPASAM tenemos muchas cosas en común con los que están peleando en todo el país (...) para aplicar este plan el gobierno y los patrones cuentan con colaboradores en nuestras propias filas. Allí lo podemos ver a Ubaldini que está borrado del mapa, Lorenzo Miguel, Triaca que de representante sindical saltó a ser el interventor de SOMISA encargado de despedir obreros (...) nos faltó un elemento: CON QUE HERRAMIENTA SALIMOS A LA PELEA (...) Nuestra propuesta para este momento: estamos divididos y no hay confianza en la dirección (...) lograr la unidad no de los dirigentes sino de LA BASE DEL YACIMIENTO eligiendo por sector a los compañeros que más confianza le tengamos (...) que la base decida (...) este organismo debe ser el encargado de recorrer escuelas, comercios el hospital la municipalidad etc. explicando el conflicto y organizando la solidaridad con los obreros (...) EL COMITÉ DE LUCHA (...). Por la defensa de la fuente de trabajo, Contra las suspensiones, No a la racionalización". "Compañeros de Hipasam", agrupación Democracia Obrera, 28/05/1991.

46 "Minuta de los compañeros del partido en Sierra Grande", 01/07/1991, p. 3.

47 "Elementos para un balance provisional", 21/11/1990, p. 2.

48 "Minuta de los compañeros del partido en Sierra Grande", 01/07/1991, p. 3.

49 Ídem, p. 3.
} 
HIPASAM") la lista de la Unidad de los Trabajadores (UTI), nombre que usa el MAS en las elecciones para la gobernación de Río Negro, bajo el lema "luche y vote". 50

El tono negativo de la minuta aumenta al tiempo que se concentra en el balance de los cinco conflictos considerados importantes y en donde pueden verse "desviaciones y adaptaciones oportunistas (electoralismo)" al régimen "democrático burgués" de parte del MAS. Los conflictos en cuestión comprenden una oportunidad fallida de ganar las elecciones en UPCN, una huelga fracasada entre los trabajadores recolectores de fruta con una intervención débil del MAS (Alto Valle de Río Negro), desorientación política para con el conflicto docente y el de la Asociación de Profesionales, aunque en HIPASAM se considera un triunfo el conflicto sostenido durante 1989, donde el MAS tuvo una intervención acertada: "se fortaleció con dirigentes nacionales y regionales y el partido tuvo una gran presencia". ${ }^{51}$ El punto más crítico es el de la dirección de la Regional Sierra Grande, donde los dardos apuntan a que las reuniones de cuadros se realizan cada quince días, sin dirección política que centralice en ese intervalo las actividades cotidianas, lo que pone a Sierra Grande bajo la órbita de la distante y desinteresada Regional Neuquén. ${ }^{52}$ Pero lo que aumenta la sensación de abandono de estos militantes de Sierra Grande es que la dirección Regional y también Nacional, se desentienden de todos estos problemas logrando que el partido se encuentre en una:

parálisis total, disgregamiento, sin línea política, casi nula la venta de prensa y una incomprensión, sorpresa total por la situación que está atravesando, siendo conscientes los compañeros que participan de esta minuta que el partido es el responsable, si bien no el único de la derrota del movimiento obrero de Hipasam. ${ }^{53}$

La segunda minuta finaliza preguntándose dramáticamente si el partido a nivel nacional realmente conocía la realidad de Sierra Grande, puesto que al filo del cierre de

\footnotetext{
${ }^{50}$ Volante "Luche y vote a la unidad de los trabajadores y la izquierda", agosto de 1990. Entre las consignas del volante se lee: "tenemos que soportar el desmantelamiento de la mina de hierro HIPASAM en Sierra Grande. Entre obreros y empleados, 1400 trabajadores y un pueblo entero dependen de HIPASAM. El Plan Cavallo que está hecho por el FMI y EEUU para bajar los salarios, entregar baratas las empresas públicas como Aerolíneas Argentinas y Entel, y despedir 100.000 estatales en estas semanas ataca todo HIPASAM (...) HIPASAM tiene solución (...) 5 medidas: 1) "declarando a Hipasam empresa pública de interés nacional para la industria siderúrgica argentina, 2) que el directorio de la empresa sea totalmente obrero (...), 3) que controle y decida sobre la producción, la administración y las finanzas de la empresa, 4) que los 10 millones de dólares necesarios para reactivarla salgan del pago de la deuda externa (...) Abajo el Plan económico Cavallo-Menem-Masaccessi. Candidatos: Carlos Segovia (APDH) gobernador, Víctor Campos (minero de Hipasam) como vice-gobernador, Aurelio Vázquez (docentes) como diputado, Roberto Mandrik (secretario general del gremio de la fruta)".

51 "Minuta de los compañeros del partido en Sierra Grande", 01/07/1991, p. 3.

${ }^{52}$ Un ejemplo de las desinteligencias que produce esta falta de una dirección arraigada en Sierra Grande ocurre durante una huelga que se desata por aumento salarial en febrero de 1991, que dura 17 días, y donde la base desborda a la burocracia "mientras el equipo del MAS una parte está de vacaciones y la otra saca un comunicado sin discusión". Luego de ese conflicto serán destituidos 3 delegados del MAS, sin que el partido denuncie la situación. "Minuta de los compañeros del partido en Sierra Grande", 01/07/1991, p. 5 y 6.

${ }^{53}$ Ídem, p. 7.
} 
HIPASAM muchos militantes obreros del equipo sindical se encontraban a la deriva: "pasaron 56 días sin cobrar (...) alguno de ellos yendo a comedores". 54

En efecto, si se revisan los periódicos del MAS durante agosto, el mes crítico en HIPASAM y mes de elecciones a gobernador en Río Negro, nada destacado se encuentra del conflicto en la mina aunque sí se subraya en un pequeño recuadro la candidatura de Aurelio Vázquez (docente) a gobernador por la UTI. ${ }^{55}$ El MAS en realidad está sumido en otro conflicto interno que protagoniza rivalizando con sus aliados electorales a nivel nacional; el copete central de uno de sus números de agosto dice: "El PC y el FRAL rompieron la UTI para defender la jubilación de privilegio de Néstor Vicente" ${ }^{~, ~ d i s p u t a ~}$ que ocupa más de una hoja del periódico ${ }^{57}$. En el mismo número un pequeño recorte de menos de media página, sobre un total de doce páginas, titula: "Sierra Grande volvió al corte de ruta". 58

Por lo demás, la performance electoral del MAS, que ya se presenta separado del PC en Río Negro, es desalentadora. En las elecciones provinciales se obtienen los siguientes resultados: UCR 35,3\% (64353 votos), PJ 26,8\% (48768), Movimiento Popular 15,4\% (28092), PC 1,5\% (2698), MAS 1,3\% (2444), PTP 0,8\% (1492). En Sierra Grande los resultados fueron: UCR 2017 votos, PJ 987, MP 188, PTP 41, MAS 110, PC 70. Como referencia de la cantidad de votos obtenidas por el MAS en otras localidades rionegrinas tenemos: Viedma 273 votos, Villa Regina 197, Roca 338 (el PC allí logra 434). ${ }^{59}$

\section{La vivencia militante de Cristóbal P.}

Mientras tanto, ¿qué ha ocurrido con la militancia de Cristóbal P? Cuando ingresa a la mina Cristóbal recuerda que no existía, más allá del sindicato, ningún tipo de contacto en sentido fuerte de los obreros con la militancia política. ${ }^{60}$ Por eso, la llegada de miembros del MAS le otorga cierta impronta novedosa a HIPASAM. Así lo recuerda:

\footnotetext{
54 Ídem, p. 7. Otros documentos regionales señalan fuertemente la percepción del fraccionamiento en que está sumido el MAS a nivel nacional, lo que imposibilita llevar a cabo "una seria discusión", proponiendo que se elija una nueva dirección que excluya "35 compañeros del viejo CC". Ver "Declaración de Río Negro", documento dirigido a la LIT (CI), al CC y al Partido, 20/07/1991.

${ }^{55}$ Ver por ejemplo Solidaridad Socialista, año IX, $\mathrm{N}^{\circ} 390,1$ de agosto de 1991

${ }^{56}$ Solidaridad Socialista, año IX, N 391, 10 de agosto de 1991.

${ }^{57}$ La polémica emerge cuando Néstor Vicente (FRAL) gestiona cobrar una jubilación de privilegio en medio del debate y las luchas de los jubilados nacionales, y donde Luis Zamora (MAS) venía de presentar un proyecto de ley de defensa del sistema previsional que contemplaba abolir las jubilaciones de privilegio. Ídem, p. 3.

58 Ídem, p. 9. El recuadro informa que el gobierno cerró HIPASAM, con el respaldo del gobernador Massaccesi y de AOMA (Riesco). Señala que sólo 120 obreros aceptaron el retiro voluntario, a pesar de que la asamblea del 24 de julio se había votado el inmediato pago de los salarios de junio y la reapertura de la mina, además de rechazar la privatización y a los interventores, por moción de Víctor Campos ("campito"). En los cortes de ruta se estima entre 1500-2000 personas.

${ }^{59}$ Diario Río Negro, 28/10/1991.

60 “el Mas estaba solo como organización de izquierda (...) y ya tenía militantes mineros, oriundos del lugar”, Entrevista a Cristóbal P., Neuquén, 05/01/2016.
} 
La militancia de izquierda tiene otras formas de acercarse a la militancia, otros modos de captar militantes. Son más incisivos, más vehementes, si se caen se levantan y siguen avanzando. Con esas características aparece una organización de izquierda que muchas veces, muchos no sabían ni quienes eran ni de dónde venían. ${ }^{61}$

Pero esa novedad ya se había hecho presente meses atrás cuando los mineros se movilizaron a la capital rionegrina:

Y ese día hicimos una olla popular y mucha juventud apareció, nos trajo platos, vasos, cubiertos, agua, pan. Y esa juventud después nos ofreció un periódico para leer. Y yo me lo llevé al periódico a Sierra Grande, y cuando tuve tiempo lo leí. ${ }^{62}$

Cristóbal P. lee con interés esa prensa, le sorprende el modo en que se denuncia a políticos regionales del PJ (Pichetto, Sodero Nievas, Rachid) por su prédica a favor de la "cirugía sin anestesia", la frase que inmortalizó al presidente Carlos Menen cuando justificaba las privatizaciones. Al poco tiempo un joven golpea la puerta de su casa en Sierra Grande: "mucho gusto (...) tengo anotada acá su dirección y venía a preguntarle si usted había podido leer el periódico que le entregaron en Viedma". Cristóbal P. remarca que el MAS fue la única organización que repartió periódicos ese día. De allí en adelante, reuniones, charlas, discusiones, y en tres meses Cristóbal P. se decide a militar en el MAS, y de inmediato participa de la lucha política por ganar el sindicato siendo elegido delegado de sector de "pelletización". Desde entonces sufre presiones por su posición opositora, como por ejemplo cuando denuncia la maniobra de Riesco para hacer votar en asamblea la publicación de un comunicado de apoyo incondicional al Directorio de HIPASAM y al rumbo económico del gobierno de Menem.

Pero el evento que marcó a Cristóbal P. ocurrió cerca del cierre de la mina. La conducción del sindicato había resuelto la realización de un Festival para conmemorar el Día del Minero (4 de diciembre) donde participarían Mercedes Sosa, León Gieco, Horacio Guaraní, entre otros. Cristóbal P. percibe que el mensaje de la conducción era otro: bajar un discurso a las bases para "hacerles ver que nos correspondía un par de días de joda, luego de un año de tanto sacrificio, sin remarcar cuánta guita se gastaría, atento a la situación que se nos avecinaba." ${ }^{63}$ Esa joda le recordaba a Cristóbal P. los festejos por el Mundial '78 para tapar la represión al movimiento obrero: "aquí se intentaba bailar y convencer que había 'HIPASAM para rato', mientras ya se delineaba en las esferas del gobierno nacional cerrar nuestra única fuente de trabajo". " $\mathrm{La}$ estrategia de Cristóbal P. fue mocionar en

\footnotetext{
${ }^{61}$ Ídem.

62 Ídem. La movilización a Viedma también es relata en las Vivencias.

63 “Vivencias...”, p. 14.

64 Ídem, p. 15.
} 
asamblea que se discuta en cada sección, en asambleas por turno, y en base a informes certeros que debía aportar el sindicato cuánta plata se gastaría y cómo, a la par que se debía acentuar el contexto crítico en el cual se encontraba la mina:

conclusión de todas estas idas y venidas se llama a asamblea general (...) alrededor de 600 compañeros (...) recuerdo en aquel momento que el "Ángel” ["ángel rubio", Riesco] se abrió paso entre los compañeros para dirigirse hacia el camión plataforma e iniciar la asamblea. Por primera vez en su trayectoria como secretario general en lugar de aplausos recibió una chifladura ensordecedora que guardo como un gran recuerdo de mi corta trayectoria como delegado de base ${ }^{65}$

Riesco será increpado por el sospechado fondo económico del Festival, y reaccionará acusando a un "grupo minúsculo" que "pone palos en la rueda". La respuesta de la mayoría de los obreros fue pedir a gritos que suba al camión el mismísimo Cristóbal P. ("el macho", tal el apodo que le pusieron sus compañeros de yacimiento), quien accede, explica su posición y a continuación logra que la votación rechace por mayoría la realización del Festival. Fue un éxito, a pesar de que Riesco persistió más allá del resultado y logró realizar el evento, pero fue, según escribe Cristóbal P., "un fiasco". A los pocos meses Riesco comenzó a anunciar no un festival, sino la eventual privatización o el cierre a secas de la mina. Sólo había que esperar los telegramas de despido, acogerse a retiro voluntario, o esperar a participar en la futura "empresa autogestionada".

Cristóbal P. cumple 41 años al cerrarse la mina, en 1991. Angustiado, se lanza a escribir sus "Vivencias..." en cuyas páginas finales se lee:

Surge el éxodo masivo y el desarraigo de familias enteras (...) dejando atrás las vivencias de sus años juveniles (...) todos los días se sucedían las mudanzas, una tras otra, el abrazo interminable con el compañero del sector de trabajo, el deseo de 'suerte compañero, hasta la próxima'. Las lágrimas y la impotencia se apoderaban tanto del que partía como del que quedada ${ }^{66}$

La primacía de la dimensión afectiva recubre todo el final de las “Vivencias...”; no hay lugar para balances políticos, conclusiones estratégicas o que califiquen lo que es, por fuera de la lógica de este particular testimonio, una dura derrota del movimiento obrero local, y del MAS en particular.

\footnotetext{
${ }^{65}$ Ídem, p. 16. Negritas nuestras.

66 Ídem, p. 18.
} 
"Yo creo que el MAS ni se enteró que escribí esto", nos confía Cristóbal P. en referencia a sus "Vivencias...", quien acusa el abandono en que el MAS deja a sus militantes en Sierra Grande una vez cerrada la mina, sin ningún espacio para la crítica al interior del partido:

Los dirigentes que había se fueron y nosotros quedamos a la deriva. Ahí pueden verse los errores que se cometieron, en no ayudar, no sostener al menos anímicamente a sus cuadros que había formado en Sierra Grande y que estábamos a la deriva ${ }^{67}$

En adelante, y por un lapso de casi doce años Cristóbal P. tendrá una vida laboral signada por fracasos económicos, contratos temporarios y despidos sistemáticos. Durante su estancia en Sierra Grande había formado pareja y con su compañera tuvieron 3 hijas. Su familia queda allí, suspendida también en las "Vivencias...", mientras Cristóbal P. parte solo hacia Neuquén donde intenta montar un pequeño quiosco, pero le va mal. Entonces hace changas, no le va mejor. Accede a mediados de los "90 a ser un "beneficiario" de la ley 2128 que otorgaba un subsidio a trabajadores desocupados: "más de una vez tuve que hacer cola para conseguir una caja de comida". Entre 1995-96 obtiene un puesto temporario en una empresa vial: "nunca dejé de buscar un trabajo que me dignificara más", que estaba construyendo un tramo de la ruta 40 en la localidad de Buta Ranquil, al norte de Neuquén. Es un trabajo que sabe realizar: perforar rocas, cargar explosivos y hacer la voladura, pero a los seis meses se termina la obra y su trabajo. Al tiempo, otra oportunidad lo encuentra en el interior neuquino: Añelo, luego Aluminé, y así, durante un lapso de seis años, temporariamente trabaja en ese tipo de proyectos que le permiten acumular ingresos y construirse una pequeña casa en la localidad de Plottier, a $15 \mathrm{~km}$ de Neuquén capital. Con todo, y a pesar de que los años '90 presentan tras la caída del Muro de Berlín un panorama desolador para todo aquel que persista en ser de izquierda, Cristóbal P. no reniega ni de la militancia ni de la izquierda y cuando llega a Neuquén se vincula a un contacto del MAS. Pero el partido ya está en franca desintegración, bajo una crisis política de dimensión internacional. ${ }^{6}$ Prosigue entonces con otros vínculos militantes y al poco tiempo ingresa al MST (Movimiento Socialista de los Trabajadores), una organización surgida como desprendimiento del MAS y que se constituye como tal en 1992. Allí se mantiene como "cuadro", sin responsabilidades de dirección ${ }^{69}$. La trayectoria laboral de Cristóbal P. es una constante búsqueda de un trabajo estable y digno que recién llegará bastante entrado el

\footnotetext{
${ }^{67}$ Entrevista a Cristóbal Paz, Neuquén, 05/01/2016.

${ }^{68}$ Las rupturas ocurren a nivel nacional dando lugar al menos a 5 fracciones (PTS, MST, FOS, PRS, LSR, etc.) y en el plano internacional también la Liga Internacional de los Trabajadores (LIT) se divide en UIT, CITO, FT, Socialismo o Barbarie, etc. Los grupos internos de peso que se desprenden del MAS serán la Tendencia Bolchevique (luego PTS) que rompe críticamente con el legado "socialdemócrata" de Nahuel Moreno, y la ortodoxa Tendencia Morenista (Luis Zamora). Como apunta Sager, a esta corriente trotskista argentina que otrora formó el MAS se los puede clasificar, luego de su ruptura, en ex morenistas, no morenistas, y morenistas. Ver Sager, op. cit.

${ }^{69}$ En el año 2007 el MST sufre una crisis interna y se divide en MST-nueva izquierda e Izquierda Socialista, donde recala Carlos P. sólo por 2 años.
} 
nuevo siglo, y en una fábrica de cerámicos bajo control obrero, con Cristóbal P. superando los 60 años de vida.

\section{Conclusión}

Buscamos a través del particular testimonio escrito y oral de Cristóbal P. entrar y salir del universo militante hacia el de las luchas sociales, indagar las prácticas políticas de sus organizaciones, y acercarnos a una porción poco conocida de la conflictiva década de los ‘90, como lo es el caso de HIPASAM y la política desplegada allí por el MAS.

Cristóbal P. se hizo militante varios años más tarde de ingresar a la mina, momento en el que el MAS desembarca y logra una inserción notable ubicando varios delegados, incluso más allá de la mina abarcando otras esferas de acción en Sierra Grande ("estaban en todos lados"), una pequeña localidad caracterizada como estratégica en los informes partidarios locales ("la concentración obrera más importante de la provincia") y directamente vinculada a la política nacional que el MAS decide concentrar en SOMISA ("volcarse por entero"), de la cual HIPASAM es proveedora ("depende totalmente de Somisa"). Es decir, HIPASAM puede considerarse una llave privilegiada para estudiar la política sindical de la izquierda y del MAS en particular.

El cierre de HIPASAM en 1991 despoja a Cristóbal P. del estatus de trabajador. Como en incontables casos anónimos, nuestro protagonista experimenta con angustia los cambios que el capitalismo en los '90 impone realizar con vistas a mantener su tasa de ganancia: privatizaciones, flexibilización laboral, desocupación, y lo hace sobre un telón de fondo menos perceptible aunque igual de trágico: la crisis de la izquierda mundial. Por eso, una suerte similar a la laboral le afecta ya como obrero militante: Cristóbal P. aprendió y sufrió de las prácticas políticas de su primera organización partidaria, el MAS: perdió su trabajo y su organización política lo abandonó. Quizás algunas señales, ausentes en el manuscrito, podrían anticipar un desenlace de ese tipo: acaso el criterio de maximizar a toda costa una posición sindical conquistada (tal el caso del díscolo militante "campito") descuidando otros perfiles no caudillescos (el propio Cristóbal P.) indicaban ya una práctica política de fuertes rasgos instrumentales que era conocida por Cristóbal P., como vimos, firmante de las minutas y balances regionales ¿Será que las sentencias críticas -aunque no menos esquemáticas- que muestran los documentos partidarios analizados (el "oportunismo", "electoralismo" y otros motes que señalaban el "desvío democratizante" del MAS) configuran los límites de lo posible de un perfil militante epocal, por un lado, como de las tensiones que experimenta una organización de izquierdas que busca ser "de masas" en un contexto sindical hostil, por otro?, ¿cuánto de esas limitaciones intrínsecas hicieron que Cristóbal P., a pesar del abandono, vuelva a buscar al MAS, y al desaparecer éste, a reintentar en otra organización, hija del MAS, que a su turno repitió la historia de fracturas internas?.

Es que las “Vivencias...” expresan también una ubicación intermedia, móvil, en la que un obrero como Cristóbal P. puede hablar ya desde su más profunda intimidad, ya 
desde una posición militante que saborea una victoria "como delegado de base", pero nunca desde un balance estratégico que las contemple, dato que nos permite arriesgar que es el formato vivencial el que permite a determinados sujetos militantes no sólo sobrellevar un universo político donde lo afectivo resulta imposible de ser traducido al lenguaje partidario, sino también porque ese universo militante ofrecería, a pesar de su instrumentalidad inherente, un tipo de afectividad moral resumida en la frase con la que Cristóbal P. mejor caracteriza a esos militantes de izquierda que llegaban a Sierra Grande: "si se caen se levantan y siguen avanzando".

\section{Bibliografía}

Aiziczon, Fernando "Construyendo tradiciones. Activistas de izquierda en las luchas de los obreros de la construcción de Neuquén a fines de los años '80", en revisa Izquierdas, Año 3, Número 5, Chile, USACH, 2009.

Disponible en http://www.revistas.usach.cl/ojs/index.php/izquierdas/article/viewFile/937/887

Altamirano, Carlos Bajo el signo de las masas (1943-1973), Buenos Aires. Ariel, 2001.

Anderson, Perry "La historia de los partidos comunistas", en Samuel, Raphael (ed.) Historia popular y teoría socialista. Barcelona, Crítica, 1984.

Arfuch, Leonor El espacio biográfico. Dilemas de la subjetividad contemporánea. Buenos Aires, FCE, 2007.

Becker, Howard Outsiders. Buenos Aires. Siglo XXI, 2009.

$66,1960$.

"Notes on the concept of Commitment", en American Journal of Sociology, núm

Benclowicz, José Estado de malestar y tradiciones de lucha, Buenos Aires, Biblos, 2013.

Bourdieu, Pierre Razones prácticas. Barcelona, Anagrama, 1997.

Brienza, Hernán Nahuel Moreno: El trotskismo criollo, Buenos Aires, Capital Intelectual, 2006.

Coggiola, Osvaldo, El trotskismo en la Argentina, Buenos Aires, CEAL, 1985.

Carrera, Iñigo "Las huelgas generales, Argentina 1983-2001: un ejercicio de periodización”, Buenos Aires, PIMSA, Documento de trabajo No33, 2001.

Fillieule, Olivier "Propuestas para un análisis procesual del compromiso individual", en Intersticios. Revista sociológica de pensamiento crítico. Vol 9, Madrid, 2015.

De Gaulejac, Vincent “Historias de vida y sociología clínica”. En revista Temas sociales 23, 1999.

González, Ernesto, El trotskismo obrero e internacionalista en la Argentina, tomo 1, Buenos Aires, Editorial Antídoto, 1995. 
Healey, Mark "El interior en disputa: proyectos de desarrollo y movimientos de protesta en las regiones extrapampeanas", en James Daniel (comp.). Violencia, proscripción y autoritarismo, 1955-1976. Nueva Historia Argentina Tomo IX, Buenos Aires, Sudamericana, 2003.

Hilb, Claudia y Lutzky, Daniel La nueva izquierda en argentina: 1960-1980. Política y violencia, Buenos Aires, CEAL, 1984.

Liszt, Gabriela "Historia y balance del MAS argentino", en Revista Lucha de clases, número 6, Buenos Aires, IPS, 2006.

Leglise Pensado, Patricia (coord.) Experimentar en la izquierda. Historias de militancia en América Latina, 1950-1990. Buenos Aires, CLACSO, 2013.

Moreno, Nahuel, El partido y la revolución, Buenos Aires, ed. Antídoto, 1989.

Neiburg, Federico Fábrica y Villa Obrera: historia social y antropología de los obreros del cemento. Tomo 1 y 2. Buenos Aires, CEAL, 1998.

Ollier, Matilde De la revolución a la democracia. Cambios privados, públicos y políticos de la izquierda argentina. Buenos Aires, Siglo XXI, 2009.

Ranciere, Jacques La noche de los proletarios. Buenos Aires, Ed. Tinta Limón, 2010.

Rivero, Cynthia "Confusión organizada, arbitrariedad conciente: imágenes en torno a la deslegitimación de las empresas del Estado", ponencia en las $9^{\circ}$ Jornadas Rosarinas de Antropología Sociocultural, Rosario, 2007.

Rofman, Alejandro Las economías regionales a fines del siglo XX. Los circuitos del petróleo, del carbón y del azúcar, Buenos aires, Ariel, 1999.

Rojo, Alicia "El trotskismo argentino y los orígenes del peronismo", en Cuadernos del CEIP, №3, Buenos Aires, Agosto de 2002

Sager, Federico "Tras las huellas del estallido partidario. Análisis de balances militantes de los años noventa sobre el Movimiento al Socialismo argentino", ponencia en III Jornadas Internacionales de Problemas Latinoamericanos. Mendoza, Argentina, 2010.

Soul, Julia, Somiseros. La configuración y el devenir de un grupo obrero desde una perspectiva antropológica, Rosario, Prohistoria, 2015.

Svampa, Maristella y Pereyra, Sebastián Entre la ruta y el barrio. La experiencia de las organizaciones piqueteras. Buenos Aires, Editorial Biblos, 2003.

\section{Diarios}

Diario Río Negro, 28/10/1991

Solidaridad Socialista, periódico del MAS, año IX, № 390, Buenos Aires, 1 de agosto de 1991. Solidaridad Socialista, periódico del MAS, año IX, № 391, Buenos Aires, 10 de agosto de 1991.

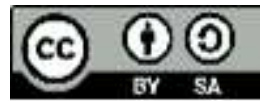




\section{Documentos}

"Al secretariado internacional, al CE, al CC y a los partidos hermanos", informe interno del MAS regional Río Negro, 20/11/1991.

Circular Interna del MAS, Buenos Aires, 13/06/1991.

“Compañeros de Hipasam”, agrupación Democracia Obrera, MAS regional Río Negro, 28/05/1991.

"Declaración de Río Negro", documento dirigido a la LIT (CI), al CC y al Partido, MAS regional Río Negro, 20/07/1991.

“Elementos para un balance provisional”, MAS regional Río Negro, 21/11/1990.

“Minuta de los compañeros del partido en Sierra Grande", MAS regional Río Negro, 01/07/1991.

Programa del MAS, Buenos Aires, julio de 1985

Vivencias de un minero de la mina de HIPASAM, Cristóbal Paz, Sierra Grande, 1991.

"Luche y vote a la unidad de los trabajadores y la izquierda", Volante electoral, MAS, Regional Río Negro, agosto de 1990

\section{Entrevistas}

Cristóbal Paz, Neuquén, 05/01/2016. 